\title{
Molecular Mechanisms through Which Peptidoglycan Induces IL-1ß Expression in Monocytic Cells
}

\author{
Hyun-Cheol Seo, Sun-Mi Kim, Sae-A Lee, Byung-Yong Rhim and Koanhoi Kim* \\ Department of Pharmacology, Pusan National University School of Medicine, Yangsan 626-870, Korea
}

Received October 16, 2012 /Revised November 21, 2012 / Accepted December 6, 2012

\begin{abstract}
This study investigated the effects of PG on IL-1 $\beta$ expression and determined cellular factors involved in PG-mediated IL-1 $\beta$ up-regulation in mononuclear cells in order to understand the molecular mechanisms underlying inflammatory responses associated with bacterial pathogen-associated molecular patterns in the diseased artery. Exposure of human monocytic leukemia THP-1 cells to PG resulted in enhanced secretion of IL-1 $\beta$ and also profound induction of the IL-1 $\beta$ gene transcript. These effects were abrogated by OxPAPC, an inhibitor of TLR-2/4. Pharmacological inhibitors such as U0126, SP6001250, Akti IV, rapamycin, and DPI also significantly attenuated PG-mediated IL-1 $\beta$ up-regulation. However, polymyxin B did not influence the IL-1 $\beta$ expression. This study indicates that PG contributes to vascular inflammation in atherosclerotic plaques by up-regulating expression of IL-1 $\beta$ via TLR-2, Akt, mTOR, MAPKs, and ROS.
\end{abstract}

Key words : Interleukin-1 $\beta$, peptidoblycan, THP-1 cell

\section{서 론}

Interleukin (IL)-1 family는 상당한 염기서열 상동관계를 공 유하고 $\beta$-pleated sheet구조(IL-1a, IL-1 $\beta$, IL-1 receptor antagonist [IL-1Ra], IL-18)를 포함하는 4가지 단백질로 구성된다. IL-1 1 는 $31 \mathrm{kDa}$ leaderless procytokine으로 바뀌고 세포 내에 서 caspase-1에 의해 잘리어 $10 \mathrm{kDa}$ 의 활성화된 형태로 된다 $[8,4]$. IL-1 receptor type 1 (IL-1R1)에 IL-1ß가 연결되면 IL-1R 보조단백질은 수용체 복합체에 의해 모이고, 세포내 신호변환 은 p38 mitogen-activated protein kinase (MAPK) 활성인산화 cascade를 통해 실행된다. 신호 cascade는 전사인자 nuclear factor kappa B (NF- $\kappa \mathrm{B})$ 와 activating protein-1 (AP-1)와 염증 성 유전자의 전사 후에 활성화되어 최고점에 달한다[2,24]. 광 범위한 신호 증폭 때문에 적은 양의 IL- $1 \beta$ 로도 상당한 생물학 적 활동을 나타낸다.

IL-1 cytokine은 내피세포, 평활근세포 및 대식세포의 강한 염증성 효과로 인해 죽상동맥경화증의 혈관벽 염증전파수단 으로 간주된다[15,21,22]. 임상 및 동물연구에서 IL-1a 또는 그 수용체 IL-1R1의 발현은 죽상동맥경화에 연계된 것으로 나타 났다. 또한, 인간 죽상동맥경화 병변에 존재하는 대식세포는 $\mathrm{IL}-1 \beta$ 를 만든다[6,18]. IL-1 $\beta$ 의 결핍은 $\mathrm{apoE}$ 가 부족한 생쥐에

\section{*Corresponding author}

Tel : +82-51-510-8064, Fax : +82-51-510-8068

E-mail : koanhoi@pusan.ac.kr

This is an Open-Access article distributed under the terms of the Creative Commons Attribution Non-Commercial License (http://creativecommons.org/licenses/by-nc/3.0) which permits unrestricted non-commercial use, distribution, and reproduction in any medium, provided the original work is properly cited.
서 죽상동맥경화증의 심각성을 감소시킨다[11]. IL-1R1 /- 생 쥐에서 IL-1R 신호차단은 유전학, 식이요법, 감염노출을 포함 한 여러 활성 성향요인과 혈관병변의 악화를 일으키는 것으로 알려진 실험조건에서 죽상동맥경화의 진행을 감소시킨다[3]. 따라서 IL-1 $\beta$ 발현의 조절을 이해하는 것은 죽상동맥경화와 긴밀한 관계가 있으므로 중요하다.

Peptidoglycan (PG)은 그람양성세균의 세포벽 구성성분이 고 평범한 사람의 장과 다른 점막의 식물군에 풍부하게 존재 한다. 점막이 아닌 곳에서 PG는 세균성 pathogen-associated molecular pattern (PAMP)로 선천적 면역 체계에 의해 인식되 므로 Toll-like receptors (TLR)를 통한 염증을 촉진한다[26,28]. 또한 PG는 단핵세포에 의한 am 32 -integrin의 발현을 유도하 고 단핵세포의 $\beta 2$-integrin에 의존적인 이동(migration)을 증 가시킨다[19]. $\mathrm{PG}$ 는 내피 세포에 의한 부착 분자의 발현과[5] 단핵세포와 대식세포에 의한 염증성 사이토카인과 케모카인 을 증가시킨다[13,27]. PG는 주로 대식세포가 풍부한 죽종부 위, 사람의 죽상동맥경화 병변에서 높은 비율로 존재한다[12]. 따라서 병변에서 주가적인 염증성 요소로 추정된다. 따라서 PG가 염증반응을 유도하는 것을 통한 신호경로의 설명은 죽 상동맥경화증에서 세균성 $\mathrm{PAMP}$ 의 역할의 현재의 지식에 기 여할 것이다. 그러나 PG가 IL-1 $\beta$ 발현을 유도하는 분자메커니 즘은 아직 밝혀지지 않았다.

본 실험에서 PG가 단핵세포와 대식세포에 의한 IL- $1 \beta$ 의 분 비에 영향을 주는지를 조사하였다. PG가 THP-1 세포주, 사람 의 급성 단구계열의 백혈병 세포주에서 IL- $1 \beta$ 의 분비를 상당 히 증가시키는 것을 발견하였다. 또한 본 실험에서는 $\mathrm{PG}$ 와 매개된 사이토카인 발현에 관계된 세포분자를 확인하고, PG 
와 매개된 IL-1 1 상향조절에 TLR2, Akt, mammalian target of rapamycin (mTOR), MAPK, and reactive oxygen species (ROS)가 관여하는 것을 발견했다.

\section{재료 및 방법}

\section{세포배양 및 시약}

THP-1 세포는 American Type Culture Collection (ATCC, Manassas, VA, USA)에서 구매하고 제안한 대로 유지하였다. 황색포도상구균으로부터 분리한 PG인 polymyxin B와 oxidized 1-palmitoyl-2-arachidonosyl-sn-phosphatidylcholine (OxPAPC)는 InvivoGen (San Diego, CA, USA)에서 구입하였 다. 내독소가 없는 bovine serum albumin (BSA), LY294002, diphenyleneiodonium chloride (DPI), N-acetylcysteine (NAC), rapamycin과 SP600125는 Sigma-Aldrich Co. (St. Louis, MO, USA)에서 구입하였다. U0126, SB202190, Akt inhibitor IV (Akti IV)는 Cell Signaling Technology (Danvers, MA, USA)에서 구입하였다. 억제제 실험에서 THP-1세포를 앞의 화학물질들을 1 시간동안 처리하고 PG $(1 \mu \mathrm{g} / \mathrm{ml})$ 를 더해 9시간 동안 자극하였고, enzyme linked immunosorbent assay (ELISA)로 배지에 분비된 IL-1 $\beta$ 의 양을 측정하고 reverse transcription (RT)-polymerase chain reaction (PCR)로 IL-1ß 유전자 전사체를 증폭시켰다.

\section{IL-1 $\beta$ ELISA}

분비된 IL-1 $\beta$ 의 양을 상용되는 ELISA kit를 제조업자의 지
시에 따라 이용하여 측정하였다(BD Biosciences, San Diego, CA, USA). THP-1 세포는 $0.1 \%$ BSA가 들어있는 RPMI medium 1640에 하룻밤 동안 배양하고, PG에 노출시킨 후 세포 배양배지를 모았다. 세포배양배지와 IL-1 $\beta$ 의 표준을 IL- $1 \beta$ 가 붙어있는 단일클론항체로 미리 코팅되어있는 microtiter plate 에 넣어주었다. 2시간 배양 후, plate를 씻고 IL-1ß에 특정한 효소-복합 다 클론성 항체를 배양하였다. Plate를 씻고 기질을 첨가하고 배양한 다음 색의 강도를 측정하였다. 배지에 존재 하는 IL- $1 \beta$ 의 양을 표준곡선에 따라 계산하였다. ELISA 결과 는 평균표준편차로 나타내었다.

\section{RT-PCR}

THP-1 세포를 0.1\% BSA가 들어있는 RPMI medium 1640 에 하룻밤 동안 배양하고 $\mathrm{PG}$ 에 노출하였다. 전체 RNA를 세포 로부터 추출하고 Moloney murine leukemia virus reverse transcriptase를 이용하여 $42^{\circ} \mathrm{C}$ 에서 1 시간 동안 역전사하였다. Primer를 첨가하고 25 cycles $\left(94^{\circ} \mathrm{C}\right.$ for $30 \mathrm{sec}, 55^{\circ} \mathrm{C}$ for 30 $\mathrm{sec}, 72^{\circ} \mathrm{C}$ for $\left.30 \mathrm{sec}\right)$ 을 $\mathrm{PCR}$ 을 실행하여 $\mathrm{IL}-1 \beta$ 전사체를 증폭 시켰다. IL-1 $\beta$ 의 primer로 5-GGACAAGGGAGGAAGATGC3 (forward)와 5-TCTTTCAACACGCAGGACAG-3 (reverse) 를 사용하고, glyceraldehyde-3-phosphate dehydrogenase (GAPDH)의 primer로 5-AAGCTCTGCGTGACTGTCCT-3 (forward)와 5-GCTTGCTTCTTTTGGTTTGG-3 (reverse)를 사 용하였다. PCR 결과를 $2 \%$ agarose gel에서 전기영동에 의해 분리하고 ethidium bromide 염색한 다음 이미지를 사진으로 찍었다. 각 band의 intensity를 IL-1 $\beta$ /GAPDH로 표시하였다.
(A)
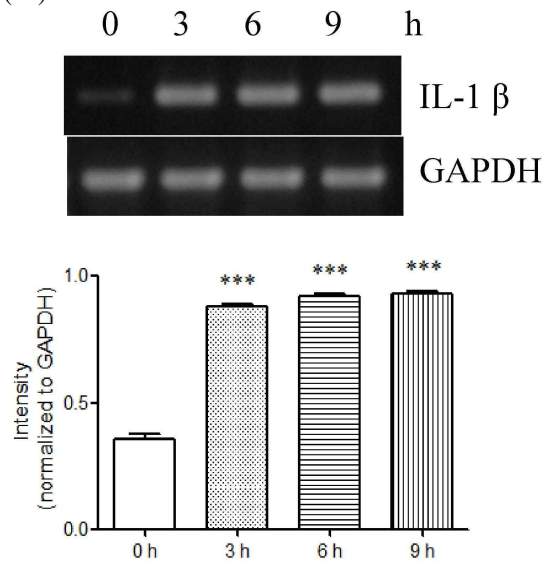

(B)
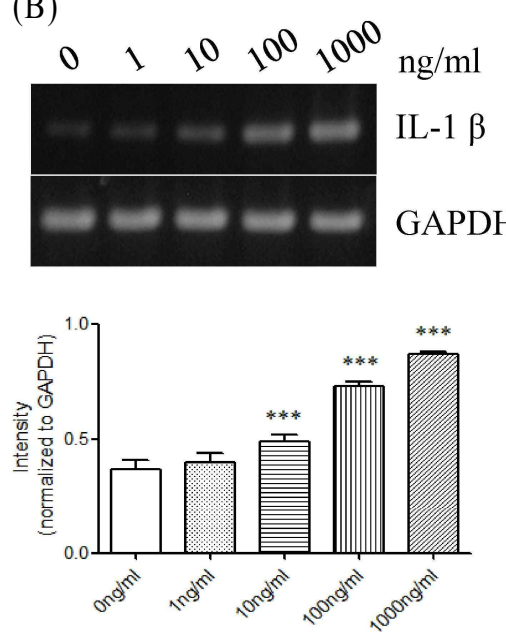

(C)

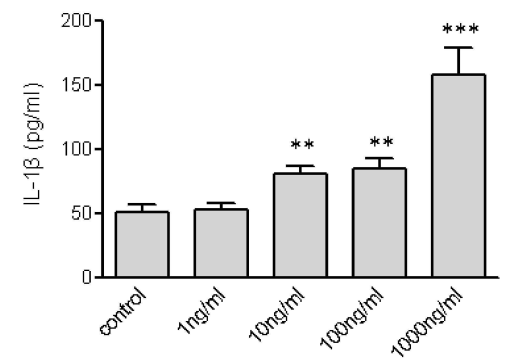

Fig. 1. Expression of IL-1 $\beta$ at the messenger and protein levels in response to PG. (A) THP- 1 cells $\left(1 \times 10^{6}\right.$ cells $\left./ \mathrm{ml}\right)$ were incubated for indicated time periods with $1 \mu \mathrm{g} / \mathrm{ml} \mathrm{PG}$. IL-1 $\beta$ gene transcripts were amplified by RT-PCR. ${ }^{* * *} p<0.001 \mathrm{vs} .0 \mathrm{hr}$. (B) THP-1 cells were incubated for $9 \mathrm{hr}$ with indicated amount of PG. IL-1 $\beta$ gene transcripts were amplified by RT-PCR. ${ }^{* * *} p<0.001$ vs. $0 \mathrm{ng} / \mathrm{ml}$. (C) THP-1 cells $\left(1 \times 10^{6}\right.$ cells $\left./ \mathrm{ml}\right)$ were stimulated for $9 \mathrm{hr}$ with or without (control) PG $(1 \mathrm{\mu g} / \mathrm{ml})$. The amount of IL-1 $\beta$ released into the medium was measured by ELISA. Data are expressed as mean $\pm S D$ ( $n=3$ replicates/group). ${ }^{* *} p<0.01$ vs. control. ${ }^{* * *} p<0.001$ vs. control. 


\section{통계처리}

통계적인 분석은 GraphPad PRISM, version 5.0 (GraphPad Software Inc., San Diego, CA, USA)를 사용하여 실행하였고, $p<0.05$ 를 통계적으로 의미있는 것으로 간주된다.

\section{결 과}

전사체와 단백질단계에서 $\mathrm{PG}$ 에 의한 $\mathrm{IL}-1 \beta$ 발현의 상향조절 대식세포에서 IL-1 $\beta$ 발현에 PG의 영향을 알아보기 위해, $\mathrm{IL}-1 \beta$ 발현의 전사수준을 RT-PCR로 조사하였다(Fig. 1A, B). PG가 없을 때 THP-1 세포에서 IL-1 $\beta$ 전사체가 상당히 약하게 발견된 반면 PG가 존재하는 경우 IL-1 3 의 전사체의 발현을
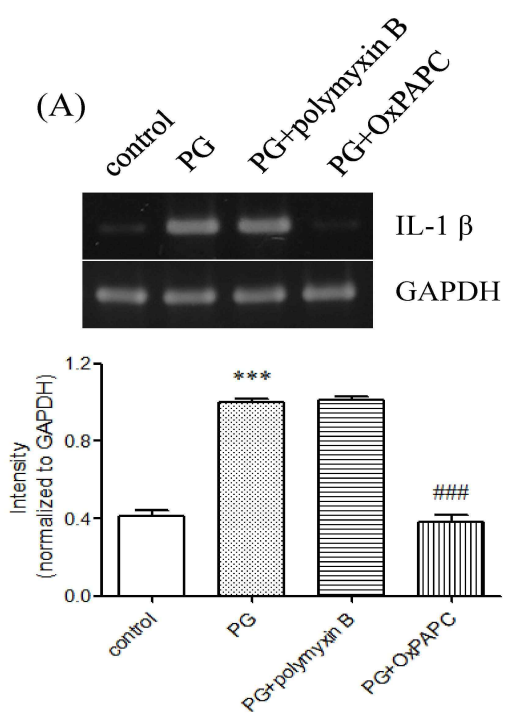

(B)

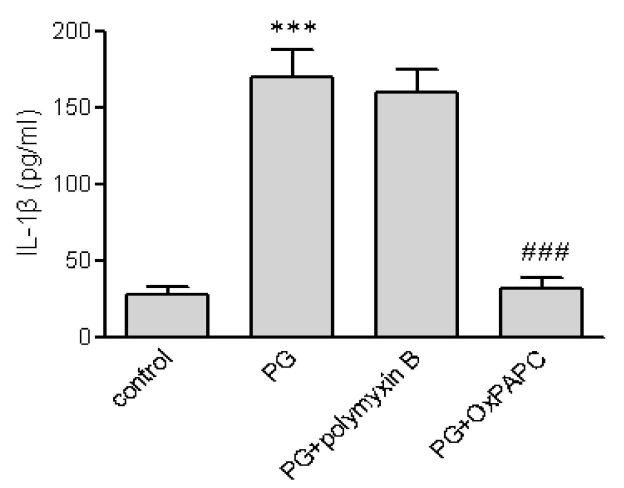

Fig. 2. Effects of OxPAPC and polymyxin B on PG-mediated IL-1 $\beta$ up-regulation. (A) THP-1 cells were stimulated for $9 \mathrm{hr}$ with or without PG $(1 \mu \mathrm{g} / \mathrm{ml})$ after treatment for $1 \mathrm{hr}$ with OxPAPC $(30 \mu \mathrm{g} / \mathrm{ml})$ or polymyxin B (10 $\mathrm{mg} / \mathrm{ml})$. IL-1 $\beta$ gene transcript was amplified. ${ }^{* * *} p<0.001$ vs. control. \#\#\# $p<0.001$ vs. PG. (B) The amount of IL-1 $\beta$ released into the medium was measured $(n=3$ replicates/group). ${ }^{* * *} p<0.001$ vs. control. \#\#\# $p<0.001$ vs. PG.
유도하였다. IL-1 전사체의 유도는 PG 처리 후 3시간 뒤부터 관찰되었고 9시간 까지 지속되었다. IL-1 전사체의 발현은 PG $10 \mathrm{ng} / \mathrm{ml}$ 이 존재했을 때 유도되었고 100 과 $1,000 \mathrm{ng} / \mathrm{ml}$ 에 서는 더 분명해졌다. PG가 사이토카인의 방출에 어떠한 영향 을 주는지 아닌지를 조사하였다(Fig. 1C). THP-1 세포는 본질

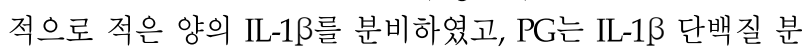
비를 상당히 증가시켰다. PG가 없는 control cell과 비교해보 면, IL-1ß 분비물의 양은 PG의 양이 $10,100,1,000 \mathrm{ng} / \mathrm{ml}$ 일때 각각 1.5-, 1.6- and 3.0-fold 증가하였다.

\section{$\mathrm{PG}$ 로 인한 IL-1 $\mathrm{B}$ 발현에 TLR2/4의 억제가 미치는 영향} $\mathrm{PG}$ 에 의한 IL-1 $\beta$ 발현에 TLRs의 관련성을 TLR2/4 억제제

(A)
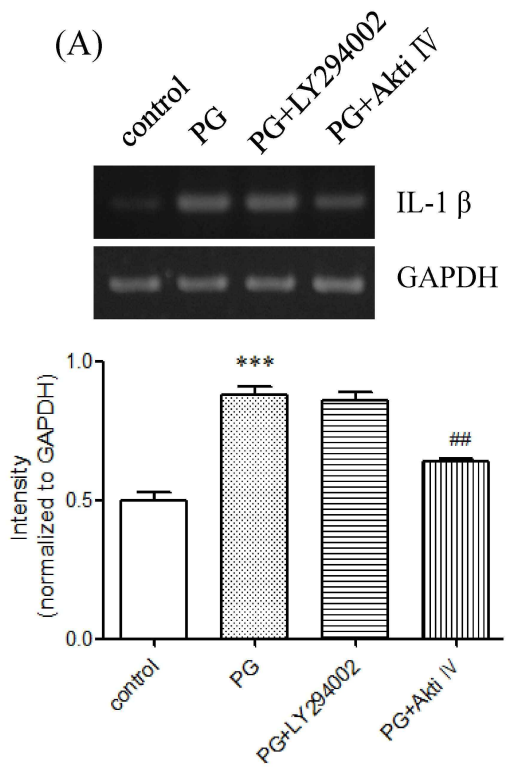

(B)

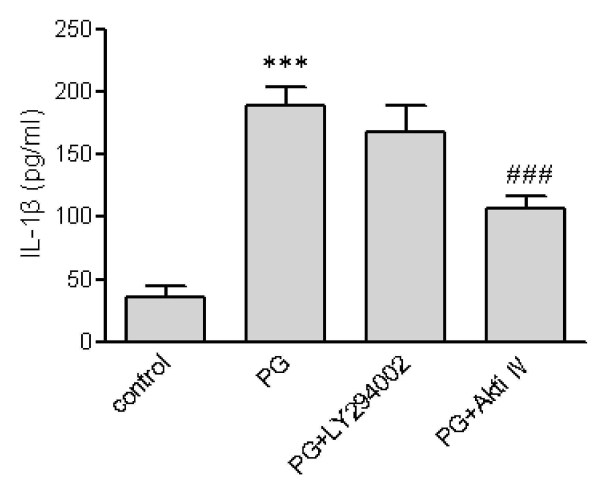

Fig. 3. Effects of LY294002 and Akti IV on PG-mediated IL-1ß up-regulation. (A) THP-1 cells were stimulated for $9 \mathrm{hr}$ with or without PG $(1 \mu \mathrm{g} / \mathrm{ml})$ after pretreatment with LY294002 and Akti IV (10 $\mu \mathrm{M}$ each). IL-1 $\beta$ gene transcript was amplified. ${ }^{* * *} p<0.001$ vs. control. \#\#p<0.01 vs. PG. (B) The amount of IL-1 $\beta$ released into the medium was measured ( $\mathrm{n}=3$ replicates/group). ${ }^{* * *} p<0.001$ vs. control. \#\#\# $p<0.001$ vs. PG. 
인 OxPAPC을 사용하여 조사하였다(Fig. 2A, B). OxPAPC은 $\mathrm{PG}$ 와 매개된 IL-1 $\beta$ 의 발현을 전사와 단백질 수준에서 억제시 켰다. PG에 의한 IL-1 1 의 분비는 OxPAPC의 존재 하에 거의 완전히 차단되어 대조군 세포만큼 줄어들고, $\mathrm{PG}$ 에서 유도된 IL-1 $\beta$ 전사체의 발현도 OxPAPC의 존재 하에 억제되었다. PG 를 준비할 때 lipopolysaccharide (LPS)로 오염될 수도 있고, 오염된 LPS가 염증성 사이토카인과 케모카인의 발현을 증가 시킬 수 있다. 따라서, LPS의 강한 억제제인 polymyxin B를 사용하여 PG에 의한 IL-1 $\beta$ 의 상향조절에 LPS가 기여하는지 아닌지를 조사하였다. Polymyxin B는 PG에 의한 IL-1B분비나 전사를 약화시키지 않았다(Fig. 2A, B).

$\mathrm{PG}$ 로 유도된 IL-1 발현에 $\mathrm{mTOR}$ 과 Akt의 역할

$\mathrm{PG}$ 는 Akt의 인산화를 증가시켜 Akt를 활성화시킨다[14].

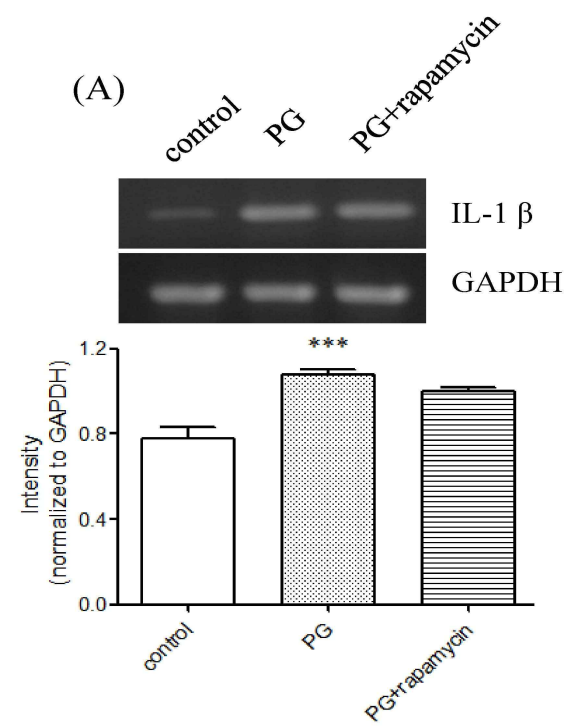

(B)

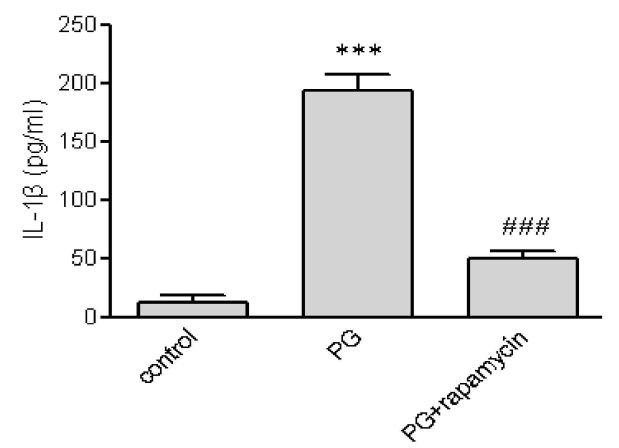

Fig. 4. Effects of rapamycin on PG-mediated IL-1 $\beta$ upregulation. (A) THP-1 cells were stimulated for $9 \mathrm{hr}$ with or without PG $(1 \mu \mathrm{g} / \mathrm{ml})$ after pretreatment with rapamycin $(100 \mathrm{nM})$. IL-1 $\beta$ gene transcript was amplified. ${ }^{* * *} p<0.001$ vs. control. (B) The amount of IL- $1 \beta$ released into the medium was measured ( $\mathrm{n}=3$ replicates/group). ${ }^{* * *} p<0.001$ vs. control. \#\#\#p<0.001 vs. PG.
PG에 의한 IL-1 $\beta$ 발현에 Akt가 관여하는 지를 LY294002와 Akti IV 사용하여 조사하였다(Fig. 3A, B). LY294002는 quercetin의 morpholine 유도체로 Akt를 활성화시키는 phosphoinositide 3-kinases (PI3Ks)를 강력히 억제한다. Akti IV 는 Akt단백질 인산화효소의 억제제다. Akti IV는 IL-1B 발현 의 전사와 단백실 수준에 상당히 영향을 주었다. Akti IV는 PG에 의한 IL-1 $\beta$ 유전자 발현의 유도를 현저히 감소시키고 IL-1 분비를 상당히 감소시켰다. 그러나 LY294002는 PG와 매개된 IL-1 $\beta$ 의 유전자 전사와 분비에 영향을 주지 않았다. $\mathrm{mTOR}$ 은 Akt의 하위분자이고 Akt의 생물학적 효과에 역할 을 담당하므로[7], mTOR의 억제제인 rapamycin을 사용하여 $\mathrm{PG}$ 에 의한 IL- $1 \beta$ 의 발현에 $\mathrm{mTOR}$ 가 작용을 하는지 조사하 였다(Fig. 4A, B). Rapamycin은 IL-1ß 발현에 영향을 주었다. 특히, rapamycin은 PG에 의한 IL-1 $\beta$ 의 전사보다는 IL-1 $\beta$ 의

(A)
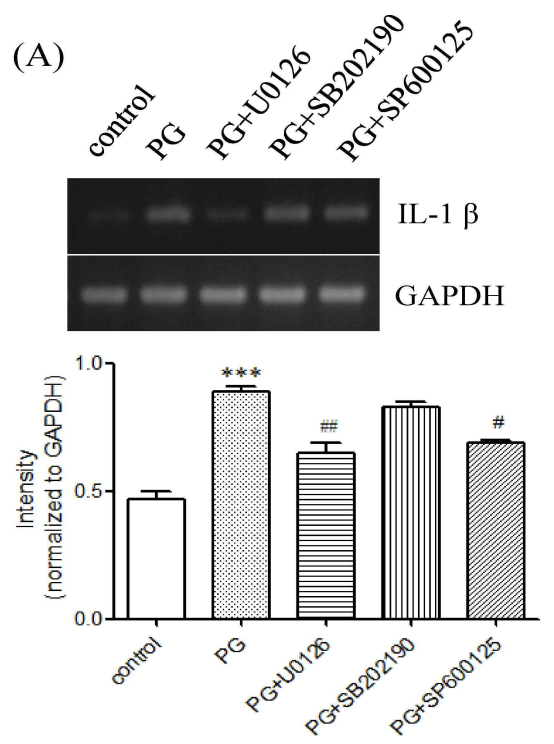

(B)

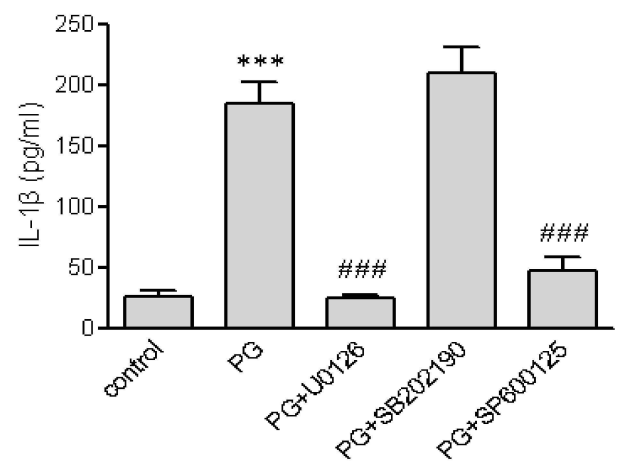

Fig. 5. Effects of inhibitors of MAPKs on PG-mediated IL-1 $\beta$ up-regulation. (A) THP-1 cells were stimulated for $9 \mathrm{hr}$ with or without PG $(1 \mu \mathrm{g} / \mathrm{ml})$ after pretreatment with indicated MAPKs inhibitors $(10 \mu \mathrm{M}$ each). IL-1 $\beta$ gene transcript was amplified. ${ }^{* * *} p<0.001$ vs. control. $\# p<0.05$ vs. PG. (B) The amount of IL-1 $\beta$ released into the medium was measured ( $\mathrm{n}=3$ replicates/group). ${ }^{* * *} p<0.001$ vs. control. \#\#\# $p<0.001$ vs. PG. 
분비를 상당히 감소시켰다.

\section{PG에 의해 유도된 IL-1ß 발현에서 MAPKs의 역할}

PG는 extracellular signal-regulated kinase (ERK), p38 MAPK, and c-jun N-terminal kinase (JNK)의 인산화를 증가 시킨다[14]. 이는 PG가 MAPKs를 활성화한다는 의미이다. PG 에 의해 유도된 IL-1ß상향조절에서 MAPKs의 역할을 조사하 기 위해, 다음과 같은 MAPK 억제제 -SB202190 (p38 MAPK 억제제), SP600125 (JNK 억제제), U0126 (ERK 억제제)를 사용 하였다(Fig. 5A, B). U0126과 SP600125는 PG가 매개한 IL-1ß 단백질의 분비 뿐만 아니라 PG가 유도한 IL-1 전사체를 감소 시켰다. 반면, SB202190는 PG가 매개한 IL- $1 \beta$ 유전자 전사와 단백질 분비를 억제하지 않았다.

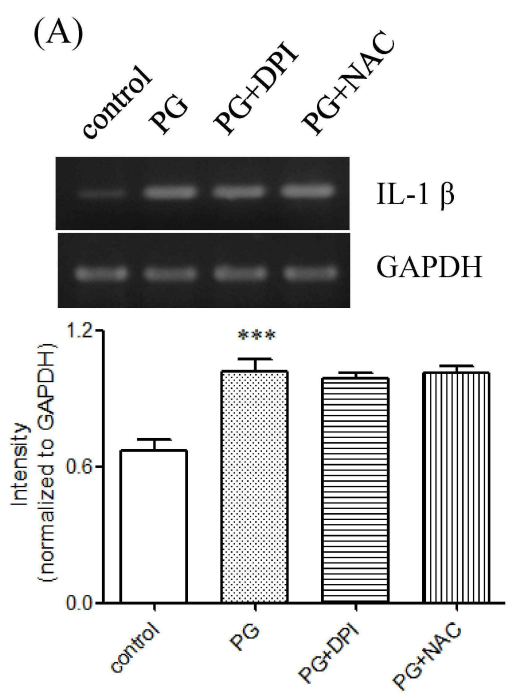

(B)

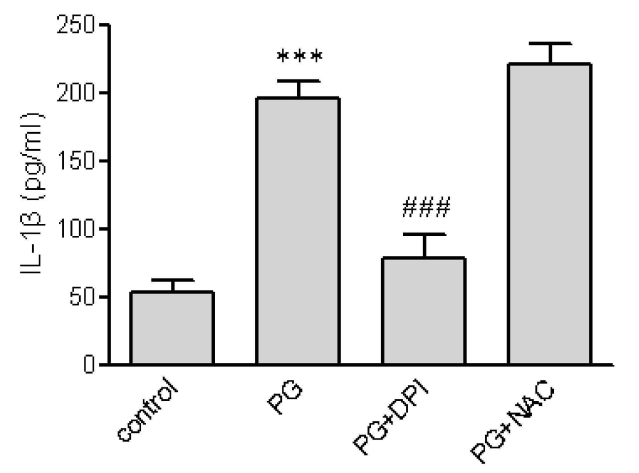

Fig. 6. Effects of ROS quenchers on PG-mediated IL-1 $\beta$ up-regulation. (A) THP-1 cells were stimulated for $9 \mathrm{hr}$ with or without PG $(1 \mu \mathrm{g} / \mathrm{ml})$ after pretreatment with DPI $(10 \mu \mathrm{M})$ or NAC $(5 \mathrm{mM})$. IL-1 $\beta$ gene transcript was amplified. ${ }^{* * *} p<0.001$ vs. control. $\# p<0.05$ vs. PG (B) The amount of IL-1 $\beta$ released into the medium was measured ( $\mathrm{n}=3$ replicates/group). ${ }^{* * *} p<0.001$ vs. control. $\# \# \#<0.001$ vs. PG.

\section{$\mathrm{PG}$ 로 유도된 IL-1 1 발현에서 ROS의 역할}

IL- $1 \beta$ 의 발현에 ROS가 역할을 하는지를 NAC와 DPI를 사 용하여 조사하였다(Fig. 6A, B). NADPH산화효소의 억제제인 $\mathrm{DPI}$ 는 PG가 매개한 IL-1 $\beta$ 분비를 상당히 억제하였고 PG가 매개한 IL-1 $\beta$ 유전자 전사에는 약간의 영향을 주었다. 그러나 $\mathrm{ROS}$ 의 직접적 scavenger인 NAC는 $\mathrm{PG}$ 가 매개한 발현에 영향 을 주지 않았다.

\section{고 찰}

본 연구는 죽상동맥경화증 병변에 세균의 구성요소로 존재 하는 PG가 전사와 단백질 수준을 IL-1 $\beta$ 발현에 상향조절 한다 는 것을 대식세포주인 THP-1세포를 사용하여 증명하였다. 이 결과는 이전에 연구된 ribonuclease 보호분석을 사용하여 인 간의 혈액 단핵세포에서 PG와 LPS에 의한 IL-1a와 IL-1 $\beta$ 발현 이 유도된다는 Wang et al [27]의 결과와 유사하다. PG는 IL-1

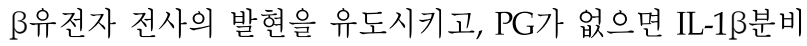
의 증가는 감지되지 않는다. PG에 의한 IL- $1 \beta$ 분비는 상당하긴 하지만, IL-1ß전사 유도의 범위에서는 중요하게 고려되지 않 았다. 그것은 PG에 THP-1 세포가 노출되면 Dinarello et al [4]에 의해 가정된 것처럼 두번째 자극의 존재에서 활동적인 $\mathrm{IL}-1 \beta$ 의 더 많은 양의 분비를 할 수 있다는 것을 가정할 수 있다.

PG가 IL-1 $\beta$ 의 발현을 유도하는 것이 분명하다 하더라도, IL-1 $\beta$ 발현에 관련된 세포분자는 아직 명확하지 않다. 본 연구 는 PG에 의한 IL-1 $\beta$ 발현에서 역할을 하는 세포인자를 확인하 였다. PG는 염증반응으로 이어지는 신호통로의 활성화를 유 도하는 TLR2에 의해 세균성 PAMP를 인식한다 $[1,10,26]$. 따라 서 TLR2/4 저해제인 OxPAPC을 이용하여 IL- $1 \beta$ 의 발현에 TLR2/4가 관여하는지를 조사하였다. OxPAPC은 IL- $1 \beta$ 의 분 비와 전사를 완전히 차단한다. 또한 발현은 완전히 억제되고, polymyxin B는 L-1 $\beta$ 발현을 억제하지 않았다. 이 결과는 PG 에 의해 유도된 IL-1 $\beta$ 발현에 TLR4 보다는 TLR2가 관여한다 는 것을 의미한다.

$\mathrm{PG}$ 는 Akt 인산화를 증가시키는데[14], 이 사실은 PG가 Akt 를 활성화시킴을 의미한다. 따라서 Akt와 Akt 활성인자인 PI3K [16]가 PG와 매개된 IL-1ß 발현에 연관되는지를 조사하

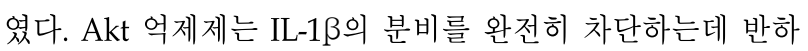
여 PI3K 억제제는 IL-1 $\beta$ 발현을 억제하지 못했다. 이 결과는 $\mathrm{PG}$ 가 매개한 IL-1ß에 Akt가 필요하다는 것을 의미한다. Akt 는 mTOR을 포함한 protein target을 통해 생물학적 효과를 달성한다[7]. 따라서 mTOR가 PG에 의한 IL-1 $\beta$ 발현에 연관되 어 있는지를 조사하였다. mTOR의 억제제인 rapamycin은 IL-1 $\beta$ 분비를 상당히 감소시키는 반면 유전자의 전사는 조금 감소시킨다. 이 결과는 rapamycin이 PG에 의한 IL-13 발현을 유전자수준보다는 단백질 수준에서 억제시킴을 의미한다. 그 
리고 이 결과는 단백질 합성에 mTOR가 책임이 있다는 것과 세포의 번역조직의 켜짐과 꺼짐에 영향을 준다는 사실과 일치 한다[20]. 떠라서 $\mathrm{Akt} / \mathrm{mTOR}$ 경로가 PG와 매개된 IL-1 $\beta$ 상향 조절에 중요한 역할을 한다는 것을 확인하였다.

MAPKs는 serine/threonine-specific protein kinases로 세 포밖의 자극에 반응하고 다양한 세포의 활성을 조절하며 PG 에 의해 활성화 된다[14]. MAPKs는 TLR-2, -4, -9 신호에서 케모카인 생산에 중요하다[25]. 그러므로 IL-1 발현에 MAPKs 가 역할을 하는지를 조사하였다. p38 MAPK는 아니지만 ERK 와 JNK의 선택적 억제는 IL-1 $\beta$ 발현을 상당히 감소시켰다. 이 결과는 PG에 매개된 IL-1 1 발현에 MAPKs의 활성화(특히 $\mathrm{ERK}$ 와 JNK)가 요구된다는 것을 가리킨다. TLR2는 PG의 반응 에서 ROS 생산에 영향을 준다는 보고[9]는 ROS가 TLR2보다 아래에서 작용하는 분자라는 것을 의미한다. 본 연구는 $\mathrm{DPI}$ 와 $\mathrm{NAC}$ 를 사용하여 ROS 또한 IL-1 $\beta$ 발현에 포함되는지 아닌지 를 조사하였다. DPI는 ROS를 생산하는 NADPH oxidase의 억제제이고, 이를 통해 ROS형성을 억제한다[17]. 세포 내 glutathione의 repletion을 위한 cysteine source 역할을 하는 thiol 복합체인 NAC는 ROS의 직접적인 scavenger 역할을 한다 [23]. DPI는 PG와 매개된 IL-1 $\beta$ 의 상향조절을 상당히 감소시 켰다. 이 결과는 ROS가 PG에 의한 IL-1 $\beta$ 상향조절에 $\mathrm{NADPH}$ oxidase가 활발히 관여함을 나타낸다.

본 연구에서는 THP-1 세포가 PG에 노출되면 IL-1 $\beta$ 분비 증가와 IL-1 $1 \beta$ 유전자 전사의 유도에 대한 결과를 보여주었고, 그 과정에 TLR2, Akt, mTOR, ERK, JNK, ROS가 참여한다는 것을 밝혔다. 이후의 연구에서는 이 분자들의 신호 cascade의 전후관계를 나타내는 connections나 crosstalk의 유형을 밝힐 필요가 있다.

\section{감사의 글}

이 과제는 2011년도 부산대학교 교수국외장기파견지원비 에 의하여 연구되었음.

\section{References}

1. Akira, S., Uematsu, S. and Takeuchi, O. 2006. Pathogen recognition and innate immunity. Cell 124, 783-801.

2. Barksby, H. E., Lea, S. R., Preshaw, P. M. and Taylor, J. J. 2007. The expanding family of interleukin-1 cytokines and their role in destructive inflammatory disorders. Clin. Exp. Immunol. 149, 217-225.

3. Chi, H., Messas, E., Levine, R. A., Graves, D. T. and Amar, S. 2004. Interleukin-1 receptor signaling mediates atherosclerosis associated with bacterial exposure and/or a high-fat diet in a murine apolipoprotein E heterozygote model: pharmacotherapeutic implications. Circulation 110, 1678-1685.
4. Dinarello, C. A. 1997. Interleukin-1. Cytokine Growth Factor Rev. 8, 253-265.

5. Dobrina, A., Nardon, E., Vecile, E., Cinco, M. and Patriarca, P. 1995. Leptospira icterohemorrhagiae and leptospire peptidolgycans induce endothelial cell adhesiveness for polymorphonuclear leukocytes. Infect. Immunol. 63, 2995-2999.

6. Galea, J., Armstrong, J., Gadsdon, P., Holden, H., Francis, S. E. and Holt, C. M. 1996. Interleukin-1 beta in coronary arteries of patients with ischemic heart disease. Arterioscler. Thromb. Vasc. Biol. 16, 1000-1006.

7. Hahn-Windgassen, A., Nogueira, V., Chen, C. C., Skeen, J. E., Sonenberg, N. and Hay, N. 2005. Akt activates the mammalian target of rapamycin by regulating cellular ATP level and AMPK activity. J. Biol. Chem 280, 32081-32089.

8. Kavita, U. and Mizel, S. B. 1995. Differential sensitivity of interleukin-1 alpha and -beta precursor proteins to cleavage by calpain, a calcium-dependent protease. J. Biol. Chem 270, 27758-27765.

9. Kavoosi, G., Ardestani, S. K. and Kariminia, A. 2009. The involvement of TLR2 in cytokine and reactive oxygen species (ROS) production by PBMCs in response to Leishmania major phosphoglycans (PGs). Parasitology 136, 1193-1199.

10. Kawai, T. and Akira, S. 2006. TLR signaling. Cell Death Differ. 13, 816-825.

11. Kirii, H,. Niwa, T., Yamada, Y., Wada, H., Saito, K., Iwakura, Y., Asano, M., Moriwaki, H. and Seishima, M. 2003. Lack of interleukin-1beta decreases the severity of atherosclerosis in ApoE-deficient mice. Arterioscler. Thromb. Vasc. Biol. 23, 656-660.

12. Laman, J. D., Schoneveld, A. H., Moll, F. L., van Meurs, M. and Pasterkamp, G. 2002. Significance of peptidoglycan, a proinflammatory bacterial antigen in atherosclerotic arteries and its association with vulnerable plaques. Am J. Cardiol. 90, 119-123.

13. Langer, M., Malykhin, A., Maeda, K., Chakrabarty, K., Williamson, K. S., Feasley, C. L., West, C. M., Metcalf, J. P. and Coggeshall, K. M. 2008. Bacillus anthracis peptidoglycan stimulates an inflammatory response in monocytes through the p38 mitogen-activated protein kinase pathway. PLoS One 3, e3706.

14. Lee, S. A., Kim, S. M., Son, Y. H., Lee, C. W., Chung, S. W., Eo, S. K., Rhim, B. Y. and Kim, K. 2011. Peptidoglycan enhances secretion of monocyte chemoattractants via multiple signaling pathways. Biochem Biophys. Res. Commun. 408, 132-138.

15. Loppnow, H. and Libby, P. 1990. Proliferating or interleukin 1-activated human vascular smooth muscle cells secrete copious interleukin 6. J. Clin. Invest. 85, 731-738.

16. Manning, B. D. and Cantley, L. C. 2007. AKT/PKB signaling: navigating downstream. Cell 129, 1261-1274.

17. Miesel, R., Sanocka, D., Kurpisz, M. and Kroger, H. 1995. Antiinflammatory effects of NADPH oxidase inhibitors. Inflammation 19, 347-362.

18. Moyer, C. F., Sajuthi, D., Tulli, H. and Williams, J. K. 1991. Synthesis of IL-1 alpha and IL-1 beta by arterial cells in atherosclerosis. Am J. Pathol. 138, 951-960. 
19. Nijhuis, M. M., Pasterkamp, G., Sluis, N. I., de Kleijn, D. P., Laman, J. D. and Ulfman, L. H. 2007. Peptidoglycan increases firm adhesion of monocytes under flow conditions and primes monocyte chemotaxis. J. Vasc. Res. 44, 214-222.

20. Shaw, R. J. and Cantley, L. C. 2006. Ras, PI(3)K and mTOR signalling controls tumour cell growth. Nature 441, 424-430.

21. Sica, A., Wang, J. M., Colotta, F., Dejana, E., Mantovani, A., Oppenheim, J. J., Larsen, C. G., Zachariae, C. O. and Matsushima, K. 1990. Monocyte chemotactic and activating factor gene expression induced in endothelial cells by IL-1 and tumor necrosis factor. J. Immunol. 144, 3034-3038.

22. Sironi, M., Breviario, F., Proserpio, P., Biondi, A., Vecchi, A., Van Damme, J., Dejana, E. and Mantovani, A. 1989. IL-1 stimulates IL-6 production in endothelial cells. J. Immunol. 142, 549-553.

23. Spagnuolo, G., D'Anto, V., Cosentino, C., Schmalz, G., Schweikl, H. and Rengo, S. 2006. Effect of N-acetyl-L-cysteine on ROS production and cell death caused by HEMA in human primary gingival fibroblasts. Biomaterials 27, 1803-1809.

24. Suzuki, H., Shibano, K., Okane, M., Kono, I., Matsui, Y., Yamane, K. and Kashiwagi, H. 1989. Interferon-gamma modulates messenger RNA levels of c-sis (PDGF-B chain), PDGF-A chain, and IL-1 beta genes in human vascular endothelial cells. Am J. Pathol. 134, 35-43.

25. Thobe, B. M., Frink, M., Hildebrand, F., Schwacha, M. G., Hubbard, W. J., Choudhry, M. A. and Chaudry, I. H. 2007. The role of MAPK in Kupffer cell toll-like receptor (TLR) 2-, TLR4-, and TLR9-mediated signaling following trauma-hemorrhage. J. Cell. Physiol. 210, 667-675.

26. Wang, Q., Dziarski, R., Kirschning, C. J., Muzio, M. and Gupta, D. 2001. Micrococci and peptidoglycan activate TLR2, MyD88, IRAK, TRAF, NIK, IKK, NF-kappaB signal transduction pathway that induces transcription of interleukin-8. Infect. Immunol. 69, 2270-2276.

27. Wang, Z. M., Liu, C. and Dziarski, R. 2000. Chemokines are the main proinflammatory mediators in human monocytes activated by Staphylococcus aureus, peptidoglycan, and endotoxin. J. Biol. Chem 275, 20260-20267.

28. Yoshimura, A., Lien, E., Ingalls, R. R., Tuomanen, E., Dziarski, R. and Golenbock, D. 1999. Cutting edge: recognition of Gram-positive bacterial cell wall components by the innate immune system occurs via Toll-like receptor 2 . J. Immunol. 163, 1-5.

\section{초록 : 펩티도글라이칸에 의한 인터루킨-1 베타 발현 기전 연구 \\ 서현철 · 김선미·이새아· 임병용·김관회` \\ (부산대학교 의학전문대학원 약리학교실)}

본 연구에서는 IL-1 $\beta$ 발현에 PG의 영향을 조사하였고, 단핵세포에서 PG에 의한 IL-1 $\beta$ 상향조절에 포함된 세 포인자를 밝혔다. PG에 사람의 THP-1 세포를 노출시키면 IL-1 $\beta$ 분비 증가뿐만 아니라 IL-1 $\beta$ 유전자 전사를 유도 하는 결과를 가져왔고, TLR-2/4의 억제제인 OxPAPC에 의해 저해되었다. U0126, SP6001250, Akti IV, rapamycin, DPI 같은 약리학적 저해제도 PG에 의한 IL-1ß의 상향조절을 상당히 약화시켰다. 그러나 polymyxin B는 IL-1 $\beta$ 발현에 영향을 미치지 않았다. 본 연구는 PG는 TLR-2, Akt, mTOR, MAPKs, ROS를 통하여 IL-1 $\beta$ 의 발현을 상향시킴을 확인하였다. 